\title{
Analyze the Economic Value of Accounting Integrity in Market Mechanism
}

\author{
Aihua Li, Lei Chen \& Baofang Dong \\ School of Business Administration, Shenyang University, Shenyang 110044, China \\ Tel: 86-24-6226-8416 E-mail: sydxlah@163.com
}

\begin{abstract}
This paper analyzes the economic value of accounting integrity, agreeing that accounting integrity can decrease trading costs, improve enterprises' operational efficiency, enlarge market shares and competitiveness, evaluate and motive economic subjects, drive the formation and development of social capitals, and actualize the economy of scale.
\end{abstract}

Keywords: Market mechanism, Accounting integrity, Economic value

Accounting, in nature, is a contract relationship. The supply of real accounting information reflects the fulfillment of accounting contract. On one hand, accounting integrity requires enterprises to follow relevant principles and system in establishing, assessing, recording, and reporting relevant accounting issues. Enterprises can choose accounting methods objectively and fairly according to the contents of business. Other social investors can believe that the accounting information supplied by enterprises according to financial rules and accounting system is exact, real, complete, and timely. On the other hand, accounting integrity requires that enterprises must offer real and fair accounting information in final reports, which should be in accordance with enterprises' objective economic conditions. That is the universal understanding and ultimate requirements for accounting integrity in market.

Value, as a basic concept of philosophy, means the significance of people's objective activity and its product to their existence and development. If certain activities and the products are meaningful to people's existence and development, and show certain utility, people confirm their value. Here, the utility means the material effect obtained by people from physical products on one hand. On the other hand, it means the "symbol" value obtained by people from spiritual products. Facts prove that the moral practice of integrity can not only help people get certain "symbol" value and "internal interests", but also make people actualize certain physical effect and "external interests". Modern market economy can realize the resource allocation by market transactions that depend on strict contracts. It is credit economy taking contracts as the base. In market economy, integrity is the best strategy and guaranty for market subjects realizing self economic interests. The economic value of accounting integrity mainly focuses on these aspects as follow.

\section{Accounting integrity can decrease trading costs for economic subjects.}

Enterprises depend on the whole process of fulfilling contracts concerning the trade of factor use right. To sign, fulfill, and supervise contracts will inevitably face costs and losses. Factor owners expect accounting integrity in enterprise contract. They do not regulate on or dispute over the sign and the fulfillment of accounting contracts, which can save costs of signing contract. In the fulfillment of accounting contract, to perform accounting items according to accounting system can save costs of fulfilling contract and supervising the fulfillment. The sincere fulfillment of accounting contract can give an exact evaluation on enterprises' fulfillment of contract, which can ensure the optimized allocation of factor resources, decreasing losses. Therefore, accounting integrity can save trading costs for enterprises. In a word, although trading costs can be saved by laws and perfect economic system, the constitution and execution of laws cost more. The less the trust is, the more formal rules and regulations are necessary. As a result, trading cost will rise. Accounting integrity can help to build a wide trust between trading partners, maintaining transaction orders, and decreasing trading costs.

\section{Accounting integrity can improve enterprises' efficiency}

The trading efficiency is determined by the rate of trading costs to trading quantities. The lower the trading costs are and the higher the trading quantities are, the higher the efficiency is. Therefore, trading costs are the key factor determining the trading efficiency. To decrease the contract trading cost is equal to the improvement of efficiency. Accounting integrity can form a stable expectation among trading partners, which improves the motives of factor owners participating in enterprises. In other words, in an economic environment that has accounting integrity, the 
quantities and the speed of contract trading are improved significantly. Accounting integrity can protect enterprises' interests against others hurts, what can improve the economic efficiency greatly. For enterprises, as contract subjects, they hold a common recognition to accounting integrity as they sign contracts. It improves the efficiency of signing contracts. For enterprises, to deal with accounting affairs based on accounting integrity can improve the efficiency of financial management and decision. For the whole society, accounting integrity can make enterprises to provide real and fair financial reports that can reflect enterprises' practical business performances and investment values. By this way, it can speed up social resources' effective allocation, decrease capital costs, and improve the whole society's economic benefit. In other words, in an environment where everybody has integrity and credit, the trade will be more active and trading net will be more developed. And transaction quantities will be high. Trading cost will be decreased significantly. Trading efficiency will be improved greatly.

\section{Accounting integrity can improve enterprises' market shares and competitiveness}

For one single economic subject, long-term and continuous accounting integrity practice will help to form a credit, exerting a powerful and virtual attraction, which can help the economic subject to take sorts of markets and improve the economic effects. Reasons are: on one hand, credit is the best financing tool. Banks prefer to offer loans for enterprises with better accounting information and good credit. Enterprises can use loans to achieve self growth, improve the business conditions, and create more values and benefits. On the other hand, credit is the best brand to attract investors. As investors are selecting investment objects, they prefer to the enterprises with exact information and social responsibilities more and more. Credit is the best display of social responsibility. An enterprise with better credit can get more "credit investments". Credit has already become an important factor for economic subjects winning benefits.

Competition is the internal mechanism of market. In front of fierce competition, honesty is the best strategy. Accounting integrity can improve enterprises' market competitiveness effectively. Under the circumstance of market economy, accounting integrity, as a virtual asset, is an important innovation of economic subjects' nice social images, and also the factor of forming the core competence. The competition between economic subjects in market, in nature, is to compete for integrity. The economic subject that respects and follows the accounting integrity can decrease trading costs and improve market competence, obtaining long-term and high economic benefits. Honesty and integrity is an important competence.

\section{Accounting integrity can evaluate and incentive economic subjects}

The trust agency relationship in enterprises determines that business operators have entrusted duties. The entrusted duties must be expressed and valued by certain means. Then, others can judge whether enterprises fulfill contracts or not. According to the accounting theory, because accounting information reports enterprises' economic conditions to operators, it can reduce operators' entrusted duties. But here it neglects that accounting is also a contract relationship. Accounting information can not prove the fulfillment of accounting contracts, because the accounting information based on different quality standards stands for different fulfillment of accounting contracts. The fulfillment of accounting contracts can be revealed and valued by accounting integrity. Accounting integrity serves as a standard for evaluating market subjects. By observing market subjects' accounting activities, people can know the degree of integrity of the subjects. In a perfect market economic system, market subjects can get benefits form its accounting integrity. In other words, market subjects who have accounting integrity can get more interests from the market, but market subjects who lack of accounting integrity can not. By this way, accounting integrity has the function of evaluating and inspiring market subjects.

\section{Accounting integrity can drive the formation and development of social capitals}

As all parties cooperate with a spirit of trust and commission, they will get more return and improve the productivity. Social capitals are composed of a series of attitudes and values, including citizens' mutual trust and cooperation. Its core relies in the mutual sincerity and trust between social members. Under the market mechanism, accounting integrity can help to build a mutual beneficial and trust social relationship between enterprises, which is a kind of social capitals. For economic growth, it has special value as the efficiency. It is not only equal to economic capitals, but also has special values that can not be generated by economic capitals.

\section{Accounting integrity can drive economic subjects actualizing scale economic effects}

Along with the development of market economy, economic division tends to be more complicated. The degree of socialization and globalization is deepening. Cooperation and partners combine competition and coordination together, realizing the economy of scale. It is the tendency. Competition makes enterprises step into coordination. And coordination aims at powerful competition. Coordination exists in one organization or between organizations. No matter what kind of coordination it is, all can improve efficiency and decrease costs, generating scale economic effects for enterprises. Accounting integrity can benefit the formation of coordination between enterprises. Trust is the basis for coordination. Only by means of mutual trust, can it form a positive coordination in an organization. Right coordination can form powerful coherence, which can make enterprises enter an ideal state. Only by mutual trust, enterprises can 
communicate widely; support each other, and share information, realizing the optimization of resources, decreasing transaction costs, and actualizing the scale effect.

To sum up, the operation of market economy depends on the developed credit system. Accounting integrity exerts an extremely important effect on the operation of market economy.

\section{References}

Lei, Guangyong. (2004). Accounting Contract Theory. Beijing: China Financial \& Economic Publishing House. P 64-65.

Wang, Xiaodong \& Cai, Chang. (2007). Economic analysis of accountant's honesty and credit. Productivity Research. No.1.

Wang, Xiaodong \& Tian, Kunru. (2006). Study on the economical roots of the accounting credit crisis and its structure of government mechanism. Modern Finance. No. 12. 